\title{
6
}

\section{HERE AND THERE}

\section{On the Ambivalence of Transitional Spaces}

\author{
Franziska Kramer
}

\section{Boundary Issues $^{1}$}

Ceal Floyer's work Bars from 2015 examines the relationship between the interior and the exterior as shown in Figure 6.1 (a photograph from the art installation in the Esther Schipper gallery in Berlin). The black window bars in powder-coated steel are part of a series of interventions in the rooms of the gallery. The window bars are set up on the inside of the window openings, and the windows remain blocked. The subdivision of the bar seems to refer to the segmentation of the existing cassette windows and creates a seemingly harmonious whole. The ordinariness of the window-bar combination evokes the image of protected single-family houses, prisons, and other exclusive or enclosed places. Floyer questions the visitor's relation to what is commonly understood as public and private or exposed and

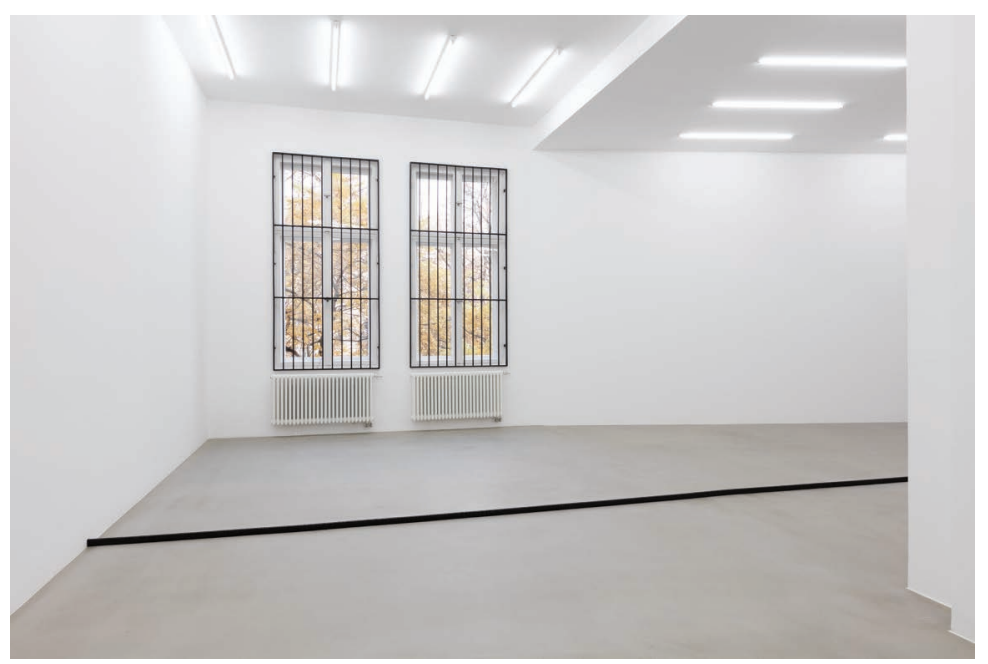

FIGURE 6.1 Ceal Floyer, Bars, 2015, Window bars made of powder-coated steel, as part of the Gallery exhibition Ceal Floyer, November 6-December 19, 2015 (C) by Andrea Rossetti. 
intimate, by displacing architectural elements and their common connotations. Initially, the specific element of the window bar evokes the image of something that excludes, which then gives rise to the question - who or what is excluded, or included, in this case? As a visitor, one is confronted with one's own image and visual habits, with one's own localization in the space or spaces one finds oneself in. Where is the interior and the exterior, and how are these attributes defined today? Ceal Floyer hints to the fact that a boundary always creates a certain ambiguity.

The ambiguity of boundaries was described in 1909 by the German-French ethnologist Arnold van Gennep, who pointed out that a boundary always creates two sides that can or cannot be defined. Gennep connected places and spaces with rituals and performances, especially in terms of the movement of a person or a group of persons for a specific reason. Body and space are therefore strongly connected with each other. ${ }^{2}$ This relationship between the bodily and the spatial has drawn attention in the social sciences, for example, sociologist Markus Schroer's analysis of spaces, places, and boundaries. He argues that the loss and transformation of boundaries require a new orientation of the body and a new behavior in places.

The ambiguity of boundaries and the increase of spatial relations hinder the localization and adaption of the body, which decreasingly encounters predetermined spatial arrangements. Spaces and bodies are somehow asked to permanently reinvent themselves. ${ }^{3}$

In today's city, new forms of boundaries were brought about by technical processes or administrative issues, like new safety regulations, for example. ${ }^{4}$ With these new forms, we might say that the readability of spaces has become a difficult issue in the city, while bodies and spaces have become fully disconnected when it comes to boundaries that are architecturally specified as thresholds._The phenomenon of ambivalent boundaries, such as thresholds, is not a recent one, as the interrelation between private and public has been continuously described as an elusive issue in various disciplines. Nevertheless, it seems that the distinction between interior and exterior spaces continues to be minimized, and as a result our cities might no longer offer the same spatial configurations that once allowed a certain level of appropriation by inhabitants. Walter Benjamin and Asja Lacis offer one example of this interaction in their 1925 essay Naples. There, they precisely describe how important the porosity of the city is for the creation of urban life and social interaction. In this case, the urban daily life in the city of Naples, where private and public were clearly defined, has been dissolved.

This chapter aims to retrace an interdisciplinary view of the meaning of boundaries and calls for a revaluation of the relevance of explicitly defined thresholds in the city. However, it is assumed that the ambivalence of transitional spaces remains a phenomenon that is necessary for creating a "successful" urban life. The uncertainty of urban spaces today might be caused by a continuous turn away from clearly defined thresholds - a process that must be interpreted once again.

\section{White Walls and Black Lines}

In 2015, the book Pardie ${ }^{5}$ presented the ongoing work on a mapping method developed by the Department of Spatial Design in order to discuss the dedication of urban spaces and reveal the contemporary spatiality of cities. Different characters of spaces were described using the colors red and blue. Determinate and indeterminate spaces are identified, with a focus on 
revealing the incongruences within the spatiality of the city, the landscape, and their spaces of intersection. The topic of structural boundaries is differentiated between enclosed and open spaces. As the publication Pardie investigates the different characters of spaces, space-forming elements such as the topography, boundaries, and thresholds are also analyzed and specified:

White lines refer to active boundaries. With reference to the architectonic formation of space, this means those boundaries that are substantially responsible for the appearance of interior spaces, for example walls. Black lines indicate "passive" boundaries. In this way, the boundaries are depicted as markings and profiles that do not participate "actively" in the formation of architectural space and instead possess structural features, for example, parcels. ${ }^{6}$

The wall can be seen as a two-sided element of interior urban spaces, which touches both the space of the street and the space of the house. Doors, windows, setbacks, stairs, and niches are connecting spaces between rooms. These elements are represented in red or light red indicating whether they are covered or uncovered. In practice, this mapping method shows the form of ambivalent boundaries. For example, an entrance situation can appear as both red and light red at the same time, which means a threshold can be covered and uncovered, as well as passive and active. ${ }^{7}$

Anyway, we might ask which meaning is determined by boundaries beyond these specifically described situations - between inside and outside - for example, by the invisible lines and administrative boundaries? What kind of boundary determines a space, and what is the role of bodily behaviors within these spaces?

On the one hand the beholder finds himself in the street amidst buildings; on the other, he remains on the street in front of buildings. ${ }^{8}$

The bodily and the spatial are two determinant and interdependent topics necessary to describe the meaning of the city, for example as discussed in the urban planning literature at the beginning of the 20 th century and before. We have seen that this relationship can be described through specific elements. The boundary is one of these determinant elements, and its spatial equivalent is the threshold. In the following, the different forms of boundaries and their description in architecture and related disciplines shall be illustrated. The attempt to invoke the different forms of boundaries should not be understood as a rigid categorization but rather be seen as a rediscovery of thematic parameters when it comes to a disciplinary understanding of thresholds.

\section{Forms of Boundaries: Structural, Administrative, Habituated, and Spatial}

A boundary produces a real or a supposed difference between two places... The effect of only a physical or imagined border is the same: it reaffirms the difference. ${ }^{9}$

Boundaries can appear in various forms. The term refers to the fact that a boundary is on the one hand a border, which means a boundary between states, and on the other hand, generally speaking, something that limits and creates two sides. According to Grimms Wörterbuch (Grimm's dictionary), the definition of the German term Grenze is a loan word from Slavic 
and indicates property and political constructs. We can gather today, under the definition of a boundary, specific descriptions of boundaries, such as Feldflur, ${ }^{10}$ Marken, ${ }^{11}$ or Rain, ${ }^{12}$ a small vacant piece of land in between two acres. Historically evolved boundaries, such as the grid of the centuratio, still define the structure and image of city and landscape. Boundaries might emerge here and there, for instance in the form of property boundaries. As an initially invisible line on the ground recorded in the administrative archives of the cities, a boundary appears once the building develops its form in a place, walls are built, and space has been built. The boundary as an intermediate space can create a dialogic relationship between the interior and the exterior. Its two-sided character is described by Arnold van Gennep, who states that the boundary is a border and connection space at the same time. ${ }^{13} \mathrm{He}$ outlines the correlation between rituals and the spatialization of a boundary. By introducing the term liminality, he describes a boundary as a transitional space between two phases, which is for instance underlined by the functionality of the Marches. ${ }^{14}$ These described elements can manifest, according to Gennep, a boundary and affect social practices. Following his argumentation, we can say that boundaries can appear as representations of cultural conditions, as narratives, histories, or even performances.

In their 1995 book Confini del paessaggio umano, Italian architects and historians Leonardo Benevolo and Benno Albrecht discuss boundaries that appear in the form of fields, town walls, mounds, or districts and thus retrace the history of appropriation of land and territory as well as the transformation of the relationship between city and landscape. Boundaries have an immediate effect, they state. On the one hand, Benevolo and Albrecht retrace the transformation of structures in the city and the landscape. On the other hand, they show how permanently the city and landscape can be determined by forms of cultural, technical, spatial, or administrative boundaries. Based on these different types, one can ask to what extent a boundary can be seen as an ambivalent spatial phenomenon that separates and unites at the same time. First, we can see that there is a certain contradiction underlying the phenomenon of boundaries in the city and the landscape. Second, it appears as a specific phenomenon that is manifested spatially. Benevolo and Albrecht describe how the loss of boundaries goes along with the dissolution of the urban habitat and how the clear allocation of towns and land has been dissolved and a new dualism between towns and land therefore evolved.

Coming back to Gennep and the described impact of boundaries as spaces of ritual, ${ }^{15}$ we can see how the relationship between the bodily and the spatial can be described especially well in relation to the architectural appearance of the threshold. According to Grimms Wörterbuch, the German Schwelle or threshold is first defined as the horizontal foundation of a construction. The origin of the word appears in two forms, whose common root is "svelo-," which means founding. A threshold is defined as a basic beam, but it could also indicate other specific architectural elements. A freer understanding of the word relates to its transitional aspect, for example as a kind of crossing. This definition describes the permeation of interior and exterior, of private and public. The second aspect of the definition refers to the relationship between the body and the threshold. Referring to the observations of Peter Sloterdijk's publication Spheres, the German architecture critic Michael Mönninger recites this relationship between body, space, and boundaries as follows:

These spaces have in common, that they are organized along the boundary between inside and outside, with us and not with us, own and foreign, inclusion and exclusion, comprehension and incomprehension. ${ }^{16}$ 
Interestingly enough, Mönninger enlarges in his article Gennep's descriptions and points toward the matter of proportionality and the relationship between things, whereas for Gennep the ritual and the place are initially two independent things, simply connected through a moment of transition, and may thus be limited to time.

In his 1977 book A Pattern Language, American architect Christopher Alexander addresses the correlation between body and space as well as between borders and places by precisely outlining the adaption and meaning of architectures as well as places and their threshold situations. Alexander presents a guideline for construction from the urban scale to the detail, mostly illustrated by simple examples based on common experiences in urban life. The described architectural elements - such as steps, doors, balconies, or loggias - can be seen as the concretization of social needs; the city is seen as a permanently transforming place.

One might think that these places of community have disappeared in today's city, but what emerges instead of defined thresholds? Laurent Stalder enlarges the description of thresholds in his Schwellenatlas from 2009, ${ }^{17}$ which reveals the transformation of thresholdbuilding elements into places of interference. Stalder introduces the controversies surrounding architecture which, on the one hand, has evolved toward open floor plans and spaces without thresholds and, on the other hand, requires new forms of thresholds in the form of technical inventions. The threshold is positioning, he states.

Given the complexity of these multiple levels of meaning, the city appears in the form of a concrete place and in the form of its possible appropriation - so to speak, as the production and the reception of threshold spaces. Boundaries can therefore appear rigid or flexible. Within this ambivalent imaginative framework, the threshold can indeed be described as an including and excluding element of the city.

\section{Thresholds as Specific Places}

In continuing the interdisciplinary overview of boundaries, the following categories can be introduced: structural, ${ }^{18}$ administrative, ${ }^{19}$ habituated, ${ }^{20}$ and spatial. ${ }^{21}$ These appear in various forms and have a certain impact, which is expressed directly or indirectly in daily life and influences the visual habits of a place's inhabitants.

In the matter of thresholds, the legibility, specificity, and transparency of spaces and their associated architectural elements seem to be crucial. Places of transition can become abodes, for example. The threshold needs to be seen as a form of architecture in relation to its time. The threshold always remains a being with a temporary character; its ephemerality is a decisive factor. But what exactly makes an ensemble of spaces successful? Michael Mönninger states that success relies on the calculated interference of urban space and building, thereby touching on the issue of porosity previously discussed by Walter Benjamin and Asja Lacis:

As porous as this stone is the architecture. Building and action interpenetrate in the courtyards, arcades, and stairways. In everything they preserve the scope to become a theater of new, unforeseen constellations. The stamp of the definitive is avoided. No situation appears intended forever, no figure asserts its "thus and not otherwise." This is how architecture, the most binding part of the communal rhythm, comes into being here. ${ }^{22}$

One would have to add that boundaries can appear as porous spatial phenomena and that the contemporary city needs this ambivalence and possibility of interpretation. Interior and 
exterior are turned inside out and vice versa. This process leads to an atmospheric densification of the existing place. The specificity of the form is herein crucial for the success of the space as the intermediary between two situations.

We should note in passing that the connection between plot (black lines) and house (white walls) has been dissolved today, although they were once historically connected to each other. The separation of plot and building can be seen exemplarily in the development of a countermovement to the tenements, for example, the Garden City Movement and the following housing developments of the 1920s. This turn started at the beginning of the 20 th century and developed the dissociation of plot and building throughout the postwar modernism, until finally the building was elevated and disconnected from the ground. ${ }^{23}$

The structural boundary has been described as part of cultural-historical heritage. The administrative aspect of the boundary is described by referring to property. The habitual boundary considers the individual's behavior, and the spatial boundary is the container of the beholder's perception. The phenomena described regarding the threshold can be seen in terms of their permanence. Places and actions are directly connected with each other. The traditional codes might remain resilient and regain a certain meaning in today's cities. This explains why a window or an entrance is more legible than recent phenomena, which are somehow disconnected from proportion and body. The same effect recurs once the familiar elements start to appear as undefined situations between public and private, and when boundary and space are disconnected. Consequently, a place loses its specificity and forces the reorientation described at the beginning of this chapter. The matter of thresholds needs to be revisited once again.

\section{Notes}

1 The term boundary is preferably used in this chapter, although in English-language usage, this gets differentiated between border, frontier, boundary, bounds, and limits. In German, the term Grenze is generally used, which can mean a border or a boundary.

2 Gennep introduces different categories of rituals, such as rituals of separation, incorporation, or transformation.

3 Schroer, M. 2006. Räume, Orte, Grenzen. Auf dem Weg zu einer Soziologie des Raums. Frankfurt am Main: Suhrkamp Verlag. See p. 291 ["Die Uneindeutigkeit der Grenzen und die Zunahme räumlicher Bezüge erschweren die Verortung und die Anpassung des Körpers der vorgegebene räumliche Arrangements immer weniger antrifft. Räume und Körper sind gewissermaßen aufgefordert, sich selbst permanent neu zu erfinden."]. Translation by the author.

4 See Stalder, L. 2009. Prä_liminarien. In: ARCH+ 191/192 Schwellenatlas, eds. S.Kraft, N.Kuhnert and G. Uhlig, pp. 24-25. Aachen: ARCH+ Verlag.

5 Schröder, U. 2015. Pardié. Konzept für eine Stadt nach dem Zeitregime der Moderne. Köln: Verlag der Buchhandlung Walther König.

6 Ibid., p. 13.

7 Ibid., p. 14. Figure 10 shows a characteristic situation in the city of Aachen: Two or three steps lead to a long corridor, from which the front building and rear building can be accessed; the entrance door is often accessed through a recessed room, which is one of the characteristics of the Rheinische Dreifensterhaus (the Rheinish three-window house).

8 Ibid., p. 13.

9 Benevolo, L. and B. Albrecht. 1995. Grenzen - Topografie, Geschichte, Architektur. Frankfurt am Main: Campus Verlag, See p. 4 ["Eine Grenze stellt eine echte oder vermeintliche Differenz zwischen zwei Orten her [...] Der Effekt einer nur physischen oder vorgestellten Grenze ist der gleiche: Sie bekräftigt einen Unterschied."] Translation by the author. From the German translation.

10 Open fields. 
11 Marches.

12 Rain.

13 See Stalder, L. 2009 Prä_liminarien. In: ARCH+191/192 Schwellenatlas, eds. S. Kraft, N. Kuhnert and G. Uhlig, 24-25. Aachen: ARCH+ Verlag.

14 See Van Gennep, A. 1909. Les rites de passage. Paris [from the German edition: Van Gennep, A. 1986. Übergangsriten. Frankfurt am Main: Campus Verlag]. p. 27.

15 Or spaces of transition.

16 Mönnninger, M. 2014. Raumwende, praktisch. Vom Nutzen des "spatial turn” für die Architektur. In: Stadt der Räume, eds. A. Denk and U. Schröder, pp. 83-94. Tübingen, Berlin: Ernst Wasmuth Verlag, see p. 84. [“Gemeinsam ist diesen Räumen, dass sie entlang der Grenze zwischen Innen und Außen, Bei-uns und Nicht-bei-uns, Eigenem und Fremden, Inklusion und Exklusion, Verstehen und Nicht-Verstehen organisiert sind.’]. Translation by the author.

17 Stalder, L. 2009. Prä_liminarien. In: ARCH+ 191/192 Schwellenatlas, eds. S.Kraft, N.Kuhnert and G. Uhlig, pp. 24-25. Aachen: ARCH+ Verlag.

18 Such as river courses or field corridors.

19 Such as plots or city borders.

20 Such as the cleaning of shoes on the doormat or stepping back from the yellow line in the train station.

21 Such as staircases or lintels.

22 Benjamin, W. p. 165 f.

23 See the author's research on the matter of the plot and the land issue, for example, as described in sITA - studies in History and Theory of Architecture, Volume 8, 2020.

\section{Bibliography}

Benevolo, L. and B. Albrecht. 1995. Grenzen - Topografie, Geschichte, Architektur. Frankfurt am Main: Campus Verlag [First edition. 1994. Confini del paessaggio umano. Rom, Bari: Laterza].

Benjamin, W. and A. Lacis. 1925. Naples. Frankfurt am Main: Frankfurter Allgemeine Zeitung.

Eigenmüller, M. and G. Vobruba. 2006. Grenzsoziologie. Die politische Strukturierung des Raumes. Wiesbaden: Verlag für Sozialwissenschaften.

Küper, S. 2015. Ceal Floyer: A Handbook. Berlin: Hatje Cantz.

Mönninger, M. 2014. Raumwende, praktisch. Vom Nutzen des "spatial turn" für die Architektur. In: A. Denk and U. Schröder (eds.), Stadt der Räume. Tübingen, Berlin: Ernst Wasmuth Verlag, pp. 83-94.

Schröder, U. 2015. Pardié. Konzept für eine Stadt nach dem Zeitregime der Moderne. Cologne: Verlag der Buchhandlung Walther König.

Schroer, M. 2006. Räume, Orte, Grenzen. Auf dem Weg zu einer Soziologie des Raums. Frankfurt am Main: Suhrkamp Verlag.

Simmel, G. 1908/2006. Der Raum und die räumlichen Ordnungen der Gesellschaft. In: M. Eigenmüller and G. Vobruba (eds.), Grenzsoziologie. Die politische Strukturierung des Raumes. Wiesbaden: Verlag für Sozialwissenschaften, pp. 15-23.

Stalder, L. 2009. Prä_liminarien. In: S. Kraft, N. Kuhnert, and G. Uhlig (eds.), ARCH+ 191/192 (Schwellenatlas). Aachen: ARCH+ Verlag, pp. 24-25.

Van Gennep, A. 1909. Les rites de passage. E. Nourry Paris [German edition: Van Gennep, A. 1986. Übergangsriten. Frankfurt am Main: Campus Verlag]. 